\title{
Ductal Pancreatic Cancer in Humans and Mice
}

\author{
D.A. TUVESON* AND S.R. HiNGORANI ${ }^{\dagger}$ \\ "Department of Medicine, Abramson Family Cancer Research Institute, \\ Abramson Cancer Center at the University of Pennsylvania, Philadelphia, Pennsylvania 19104; \\ ${ }^{\dagger}$ Fred Hutchinson Cancer Research Center, Seattle, Washington 98109
}

\begin{abstract}
Pancreatic ductal adenocarcinoma (PDA) eludes early detection and resists current therapies, earning its distinction as the most lethal malignancy by organ site in the western world. This dire reality prompted extensive yet generally disappointing efforts to generate transgenic mouse models of this malignancy. Recently, mutant mice that develop pancreatic intraepithelial neoplasms (PanIN), the presumed preinvasive stage of PDA, were produced by conditionally expressing an endogenous oncogenic Kras allele in the developing murine pancreas. Mice with PanIN demonstrated promise in the pursuit of biomarkers of early pancreatic cancer, and, importantly, such mice eventually developed and succumbed to PDA after a long latency, establishing PanINs as true precursors to the invasive disease. Furthermore, the incorporation of conditional mutations in tumor suppressor alleles known to be altered in human PDA synergized with oncogenic Kras to produce advanced PDA with a short latency, recapitulating central pathophysiological events in human PDA. These models facilitate a variety of biological and clinical investigations such as explorations of the cellular origins of PDA and the development of treatment strategies for advanced PanIN and PDA. In addition, lessons from modeling PDA may be applicable to other tumor types and illuminate general principles of carcinogenesis.
\end{abstract}

Animal models of cognate human conditions permit the rigorous exploration of mechanisms of disease pathogenesis and provide systems to devise and test therapeutic and detection strategies. Although inbred mouse strains offer many advantages over other animals for investigations of malignant disease, mice unfortunately do not develop PDA spontaneously or even following carcinogen treatment. Recent technological developments in conditional gene targeting have enabled the generation of mutant mouse cancer models of PanIN and PDA that closely mimic human pancreatic cancer and are thus suitable for investigations of the human disease process. In this paper, we summarize the knowledge of the human disease that has informed the ability to generate accurate mouse models of pancreatic cancer and describe potential biological and clinical applications.

\section{EPIDEMIOLOGY OF PANCREATIC CANCER}

Epithelial carcinomas account for the majority of cancer deaths in the United States, and among them, pancreatic cancer is the fourth most common with the highest case-fatality ratio. Pancreatic ductal adenocarcinomas (PDA) comprise more than $90 \%$ of pancreatic cancer cases and are its most lethal form among an assortment of additional histological subtypes including cystic neoplasms, acinar carcinomas, and islet cell endocrine tumors. Risk factors associated with the development of PDA include increased age, tobacco usage (Silverman et al. 1994), African heritage (Ahlgren 1996), and a family history of pancreatic cancer (Lynch et al. 1996). Despite the relatively large numbers of patients stricken with PDA, estimated at 32,180 for 2005 , our expanding knowledge of critical aspects of this disease remains terribly inadequate and undoubtedly contributes to our inability to intervene meaningfully. The impetus to investi- gate the biological underpinnings of PDA is further motivated by the predicted doubling in PDA incidence over the next two decades as the population ages (Hruban et al. 2006a). Nonetheless, the public investment in pancreatic cancer research is woefully inadequate relative to other malignancies, and consequently, the number of investigators pursuing PDA is unfortunately restricted.

\section{GENETICS OF PDA AND PanIN}

PDA is thought to evolve from a preinvasive precursor state termed pancreatic intraepithelial neoplasms (PanINs) because PanINs demonstrate cytological and genetic changes that reflect those evident in invasive PDA. PanINs are divided into three stages characterized by increasing degrees of cellular and architectural atypia. PanIN-1A lesions are flat and contain tall columnar ductal cells in distinction to the short cuboidal cells that line normal pancreatic ducts; PanIN-1B lesions additionally demonstrate mild papillary architecture in the ducts but no nuclear atypia; the PanIN-2 stage signifies cells with moderate nuclear atypia and loss of cellular polarity; PanIN-3s represent the carcinoma-in-situ stage of pancreatic cancer, characterized by marked atypia, dysregulated growth, cribriform structures, and pinched-off clusters of epithelial cells within the ductal lumen. Molecular studies from a limited number of resected human PanIN specimens demonstrate oncogenic KRAS mutations in PanIN-1A/B (35-43\%) that increase to the majority of PanIN-3 examined (86\%) (Klimstra and Longnecker 1994; Moskaluk et al. 1997; van Heek et al. 2002), followed by p16INK4a/ARF loss in PanIN-2 (55\%) (Wilentz et al. 1998), and finally, $p 53$ mutation and loss of DPC4/SMAD4/MADH4 and BRCA2 in a minority of PanIN-3s (21-31\%) (DiGiuseppe et al. 1994; Goggins et al. 2000; Wilentz et al. 2000). These mutational frequencies approach those in advanced PDA tissue samples 
and cell lines, including activating mutations in $K R A S$ ( $>90 \%$ samples) and inactivating mutations in the tumor suppressor genes p16INK4a (>95\%), p53 (50-75\%), DPC4/SMAD4/MADH4 (55\%), and BRCA2 (5-10\%) (Jaffee et al. 2002). Less frequent mutated genes include $L K B 1$ (5\%), TGF $\beta$ and Activin receptors (4\%), MKK4 (4\%), FANCC and FANCG $(<5 \%)$, AKT2 (10-20\%), and MYB $(10 \%)$ (Hansel et al. 2003; Rogers et al. 2004). Of course, these findings do not establish unequivocally that PanINs progress to invasive ductal carcinomas, nor do they exclude the possibility of other pathways to such cancers. Indeed, extensive genetic heterogeneity often exists among similar PanINs found within a given specimen (Rozenblum et al. 1997). Finally, although PanIN-1As are commonly identified in autopsy studies from the general population (Kern 2000), PanIN-3 specimens are difficult to obtain, and thus, our knowledge of the molecular events critical for the progression from PanIN to PDA remains quite limited.

Interestingly, many of the genes mutated in PanIN and invasive pancreatic cancer are present as germ-line mutations in several familial cancer syndromes with a predisposition to pancreatic cancer, including familial atypical multiple mole and melanoma (FAMMM) syndrome, Peutz-Jeghers syndrome (PJS), the breast cancer and ovarian cancer syndrome type II (BRCA2), and hereditary nonpolyposis colon cancer (HNPCC). These syndromes are associated with monoallelic germ-line mutations of the tumor suppressor genes p16INK4a (Goldstein et al. 1995), LKB1/STK11 ( $\mathrm{Su}$ et al. 1999), BRCA2 (Goggins et al. 1996; Thorlacius et al. 1996), and $h M L H 1 / h M S H 2 / h M S H 6$ (Lynch et al. 1985), respectively. Finally, patients with hereditary pancreatitis are also at a substantial risk for developing PDA (Lowenfels et al. 1997). Unfortunately, little is known about the role of these mutant genes in the development of sporadic and familial pancreatic cancer, due in part to the lack of identifiable early-stage patients. Furthermore, it is hypothesized that the major cause(s) of inherited susceptibility to pancreatic cancer remains to be identified (see, e.g., Eberle et al. 2002).

\section{CLINICAL CONSIDERATIONS IN PANCREATIC CANCER}

The poor outcome of patients with PDA has been attributed to the advanced stage of disease at diagnosis, the poor response to systemic and local therapies, and the aggressive biological nature of the disease. Early pancreatic cancer goes undiagnosed for a number of reasons, including anatomical location, nonlocalizing symptoms, and a lack of adequately sensitive and specific biomarkers of disease (Konner and O'Reilly 2002). Patients oftentimes develop a clinical prodrome that can include vague upper gastrointestinal symptoms, jaundice, adult-onset diabetes, unexplained pancreatitis, back pain, and weight loss. Initial evaluation includes radiologic assessment with transabdominal and/or endoscopic ultrasound (EUS), computed tomography (CT), and/or magnetic resonance imaging (MRI) to identify suspicious pancreatic masses in a patient, followed by definitive diagnosis established by direct biopsy of a pancreatic mass. Notably, approximately $80 \%$ of patients present with radiographically evident unresectable pancreatic cancer at the time of initial diagnosis (Warshaw and Fernandez-del Castillo 1992a).

Efforts to improve the early detection of PDA include surveillance EUS in patients at high risk for the development of PDA (Canto et al. 2004) and the development of molecular markers of early disease. Serum CA (carbohydrate antigen) 19-9 and, less commonly, CEA (carcinoembryonic antigen) are tumor markers that can be used to follow response to therapy and disease recurrence in patients who present with elevated levels at diagnosis. However, neither marker is adequate for primary detection. Many of the genetic events described above, most notably $K R A S$ activating mutations, have been investigated in potential disease-detection strategies. KRAS mutations have been searched for in serum (Tada et al. 1993; Maire et al. 2002), pancreatic secretions (Berthelemy et al. 1995; Queneau et al. 2001), fine-needle aspirates (Villanueva et al. 1996; Mora et al. 1998), duct brushings (Van Laethem et al. 1995), and stool specimens (Caldas et al. 1994). However, none of these tests demonstrated the requisite sensitivity and specificity to be useful as a general screening tool. The same is unfortunately true of a number of other potential targets, including hTert (telomerase catalytic subunit) (Uehara et al. 1999), matrix metalloproteinase-2 (MMP-2) (Yokoyama et al. 2002), and, more recently, aberrantly methylated promoter $\mathrm{CpG}$ islands of key genes (see, e.g., Fukushima et al. 2002). Novel labeling and fractionation methods for pancreatic tissue (Chen et al. 2005), serum proteins (Yu et al. 2005), and secreted proteins (Gronborg et al. 2006) coupled with tandem mass spectrometry have suggested additional candidate markers which await validation. Although these techniques continue to evolve in sophistication, to date, no marker or method has proved adequately robust, or able to detect sufficiently early disease, to significantly affect overall patient survival.

Surgical resection of a localized pancreatic tumor is currently the only hope for cure, with multi-modality therapies offering only limited palliative benefit to patients with advanced disease. Despite treatment, less than $20 \%$ of all patients will be alive 1 year after diagnosis, and less than $5 \%$ at 5 years (Warshaw and Fernandez-del Castillo 1992a). Even among the carefully selected $5-15 \%$ of patients who present with resectable disease and undergo surgery, the 5-year survival is still approximately $20 \%$ (Warshaw and Fernandez-del Castillo 1992b). For the small subset of patients with diploid DNA content, disease-free lymph nodes, and small primaries (less than 1 $\mathrm{cm}$ ), an elevated 5-year survival is observed (Crist et al. 1987; Trede et al. 1990; Allison et al. 1998). Importantly, however, many of even these highly selected patients still succumb from recurrent and metastatic disease (Allison et al. 1998; Trede et al. 2001). The chemotherapeutic agent gemcitabine has been the mainstay for the treatment of advanced pancreatic cancer for the past decade, due to a modest increase in median survival when compared to 5fluorouracil (5-FU) (5.6 months vs. 4.4 months) and a measurable increase in a patient's quality of life index 
(Burris et al. 1997). Radiotherapy is offered in combination with 5-FU as an adjuvant therapy for patients with resected PDA and in some patients with locally advanced and unresectable PDA, although the precise benefit of radiotherapy is still under evaluation. Immunotherapeutic (Jaffee et al. 2001; Laheru and Jaffee 2005) and immunomodulatory (Picozzi et al. 2003; Picozzi and Traverso 2004) approaches are also being explored as a means to prevent recurrence in resected PDA patients.

Molecular therapies that target the autonomous or noncell-autonomous compartments of PDA may improve upon the limited efficacy of gemcitabine for advanced pancreatic cancer patients. The most logical therapeutic agents for PDA would appear to be oncogenic KRAS inhibitors (Brummelkamp et al. 2002); however, none currently exists, and KRAS is unfortunately considered an intractable drug target. Nevertheless, signaling pathways downstream of oncogenic KRAS, such as the MAP kinase and the PI3-kinase cascades, may serve as suitable surrogates for oncogenic KRAS; suitable agents that inhibit these pathways are currently or will shortly be evaluated in patients. Additionally, preclinical and clinical investigations are under way with agents designed to interrupt a number of signaling pathways in PDA including PDGFR, VEGFR, EGFR, Her-2/Neu (Hansel et al. 2003), Hedgehog (Berman et al. 2003; Thayer et al. 2003), and Notch (Miyamoto et al. 2003). Indeed, the epidermal growth factor receptor antagonist erlotinib was recently approved by the FDA for administration in combination with gemcitabine in advanced pancreatic cancer patients after demonstrating a modest increase in median survival and prolonged survival in a subpopulation of patients (Tang et al. 2006; M. Moore, unpubl.). The rapid progression of PDA permits most patients only one opportunity to enroll in an investigational study and, thus, methods that would reliably predict efficacy of specific therapeutic agents for specific patients are sorely needed.

\section{MODELS OF MURINE PanIN AND PDA}

Several early attempts to produce a genetically engineered murine model of PanIN and PDA were unsuccessful. For example, "knockout" mice harboring constitutive or conditional mutations of DPC4/SMAD4/MADH4 (Sirard et al. 1998; Yang et al. 2002), BRCA2 (Suzuki et al. 1997), p16INK4a/ARF (Serrano et al. 1996), and Trp53 (Donehower et al. 1992) did not develop PanIN or PDA, suggesting that tumor suppressor gene loss alone does not initiate pancreatic cancer. Alternatively, a number of transgenic "oncomouse" strains were described as developing murine exocrine pancreatic cancer, but none faithfully recapitulated the cardinal features of PanIN or PDA. The majority of the published transgenic models involved the expression of oncogenes or growth factors from heterologous promoters that were most active in acinar cells of the pancreas. These models generally demonstrated diffuse acinar metaplasia and acinar carcinoma (Quaife et al. 1987). Several models reported pancreatic "acinartubular-ductal" transdifferentiation, and neoplasms found in these mice share some properties with human pancre- atic serous cystadenocarcinoma (Bardeesy et al. 2001) and ductal carcinomas (Wagner et al. 2001). However, the relevance of acinar-tubular-ductal transdifferentiation in human ductal pancreatic cancer remains speculative, with the direct transformation of ductal epithelial cells or pancreatic stem cells serving as an alternative model (Reya et al. 2001). For example, two strains of genetically engineered mice that directed expression of oncogenic Kras alleles from promoters predominantly active in mature acinar cells, MIST1 (Tuveson et al. 2006) and Elastase (Grippo et al. 2003), have been described. As expected, most MIST1-Kras $4 B^{G 12 D}$ and Elastase-Kras ${ }^{G 12 V}$ mice developed acinar hyperplasia and neoplasia, although MIST1-Kras $4 B^{G 12 D}$ animals additionally developed a mixed histological spectrum that included cystadenocarcinoma and preinvasive cancer with ductal features but without classic PanIN. Intriguingly, the direct expression of oncogenic $\mathrm{Kras}^{G 12 V}$ in the mature ductal compartment by virtue of a transgenic Cytokeratin 19 promoter also failed to generate PanIN or PDA, although occasional ductal hyperplasia was noted (Brembeck et al. 2003). Finally, mice bearing a latent oncogenic Kras ${ }^{G 12 D}$ allele that becomes active somatically following a stochastic recombination event succumb to lung cancer and do not demonstrate any pancreatic neoplasia (Johnson et al. 2001). Perhaps not surprisingly, there was no evidence that the recombination event required to activate the latent $\mathrm{Kras}^{G 12 D}$ allele had ever occurred in the pancreata of these mice. These findings notwithstanding, $K R A S$ mutations can be identified at high frequency in PanIN-1A in vivo, and in the absence of other obvious genetic mutations, suggesting that they do indeed participate in the initiation of tumorigenesis (Hruban et al. 1993; Yanagisawa et al. 1993; Caldas et al. 1994; Tada et al. 1996; Moskaluk et al. 1997; Terhune et al. 1998; Luttges et al. 1999). Another possible explanation for the lack of effective Kras-dependent murine pancreatic cancer models is that oncogenic $R A S$, when ectopically expressed at supraphysiological levels in primary cells, induces cellular senescence rather than proliferation (Serrano et al. 1997). Indeed, activating endogenous expression from a conditional targeted "Lox-Stop-Lox" (LSL)-Kras ${ }^{G 12 D}$ allele caused immortalization and proliferation of primary fibroblast cultures, as opposed to senescence (Jackson et al. 2001; Tuveson et al. 2004). Physiological expression of this conditional LSL-Kras ${ }^{G 12 D}$ allele alone and in combination with endogenous mutations in pertinent tumor suppressor genes ultimately led to the development of faithful models of PanIN and PDA.

The first murine model of PanIN was generated by directing the conditional expression of an endogenous $L S L$ $\operatorname{Kras}^{G 12 D}$ allele to pancreatic progenitor cells with either a Pdx1-Cre or P48-Cre allele (Hingorani et al. 2003). The entire spectrum of PanINs occurred in compound mutant mice with complete penetrance, and murine PanINs (mPanINs) were histologically indistinguishable from human PanINs, including the presence of an abundant stromal reaction in advanced PanIN (Fig. 1). Analyses of aged cohorts of mice demonstrated that mPanINs progress temporally and, furthermore, older mice harbor- 

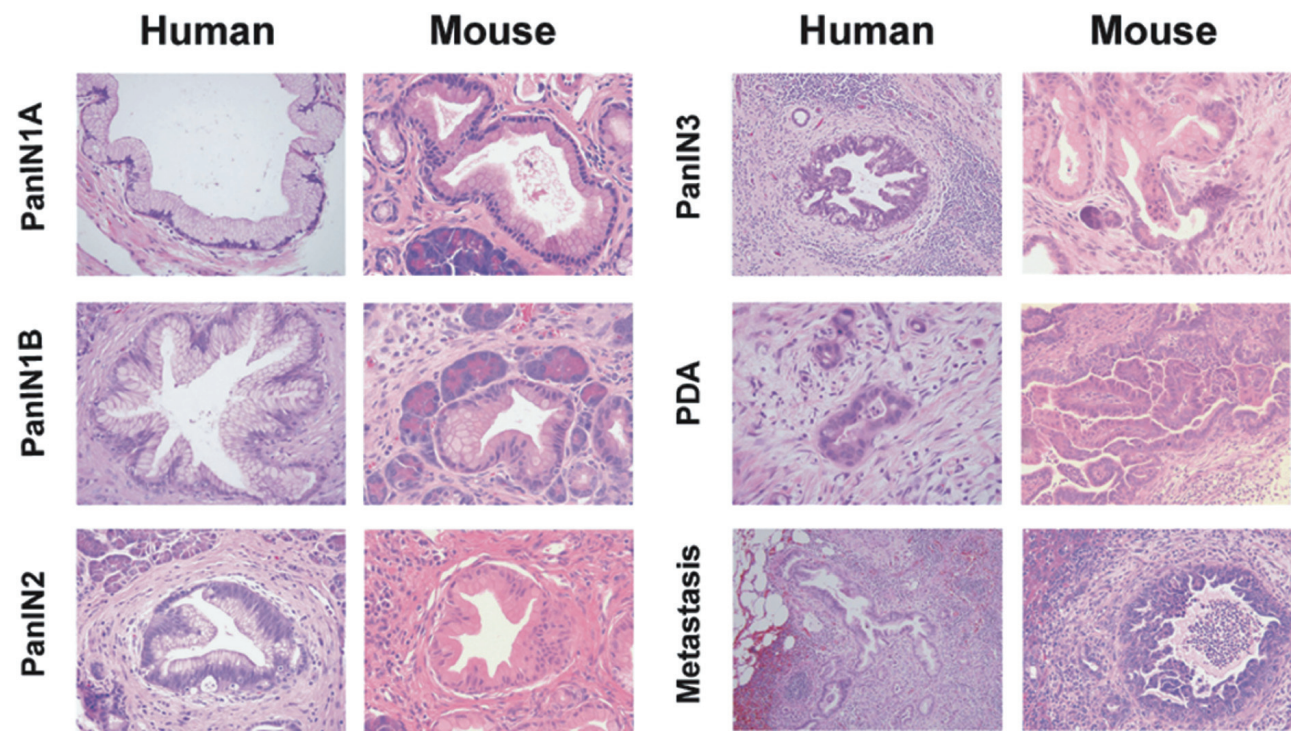

Figure 1. Histological similarity between human and murine pancreatic cancer progression.

ing mPanINs spontaneously developed PDA after a prolonged latency, supporting the premise that mPanINs were truly preinvasive neoplasms. The slow progression of mPanIN to PDA also meant that this mouse model offered the unique opportunity to identify biomarkers of PanIN. Indeed, experiments analyzing the low-molecular-weight serum proteome suggested that specific patterns of biomolecules could distinguish mPanIN mice from controls, although individual biomarkers await definitive identification. This finding was reproduced in a limited fashion by others expressing an endogenous $L S L$ $\mathrm{Kras}^{\text {GI2V-IRES- } \beta G e o}$ allele in the pancreas, in which PanIN1A-like lesions were described (Guerra et al. 2003). Thus, the murine model of PanIN was successfully produced by expressing an endogenous allele of oncogenic $\mathrm{Kras}^{G 12 D}$ at physiological levels in the developing pancreas, clarifying the gatekeeper role of Kras mutation as the initiating event in PanIN and PDA.
The mouse PanIN model also served as an ideal platform to generate models of advanced PDA by incorporating conditional tumor suppressor gene mutations in the pancreas while concomitantly expressing $\operatorname{Kras}^{\text {G12D }}$. Indeed, the conditional biallelic deletion of the Ink4a/ARF locus (Aguirre et al. 2003), or the heterozygous expression of $\operatorname{Trp} 53^{R 172 H}$ (Hingorani et al. 2005), cooperated with $\operatorname{Kras}^{G 12 D}$ to produce lethal and metastatic PDA with a significantly shortened latency. Metastatic sites included the liver, lung, mesentery, adrenal glands, celiac plexus, and diaphragm, closely resembling the patterns of disease spread observed in patients (Fig. 2). Furthermore, mice with advanced disease oftentimes presented with significant cachexia and hemorrhagic ascites, mimicking the systemic effects observed in patients. These models of advanced PDA confirmed the importance of the tumor suppressor genes previously implicated in human pancreatic cancer and
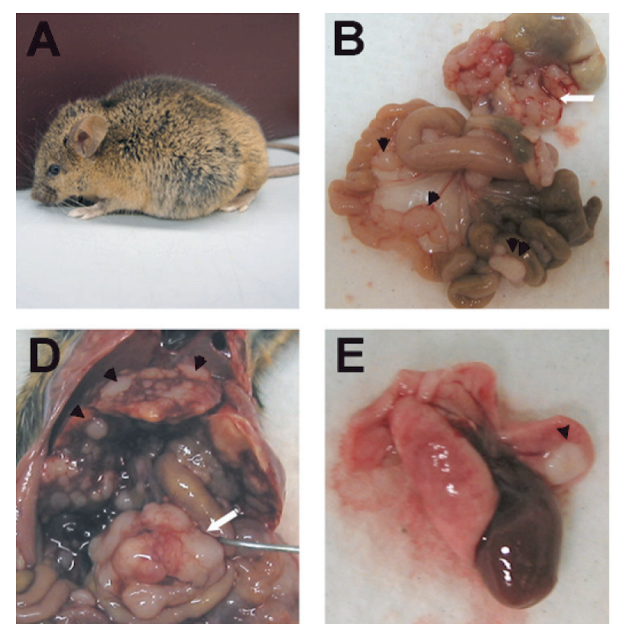
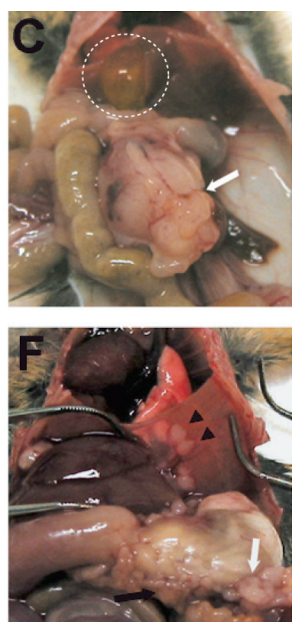

Figure 2. Clinical and pathological sequelae of advanced and metastatic PDA in mice. $(A)$ Photograph of mouse presenting with cachexia, lethargy, and abdominal distention. (B) Primary PDA at the head of the pancreas (white arrow) and mesenteric metastases (arrowheads). (C) Gall bladder distention (dotted circle) due to primary PDA tumor (arrow). (D) Liver metastases (arrowheads) from primary PDA (arrow). (E) Lung metastasis (arrowhead). $(F)$ Diaphragmatic metastases (arrowheads) and primary PDA (arrow). 


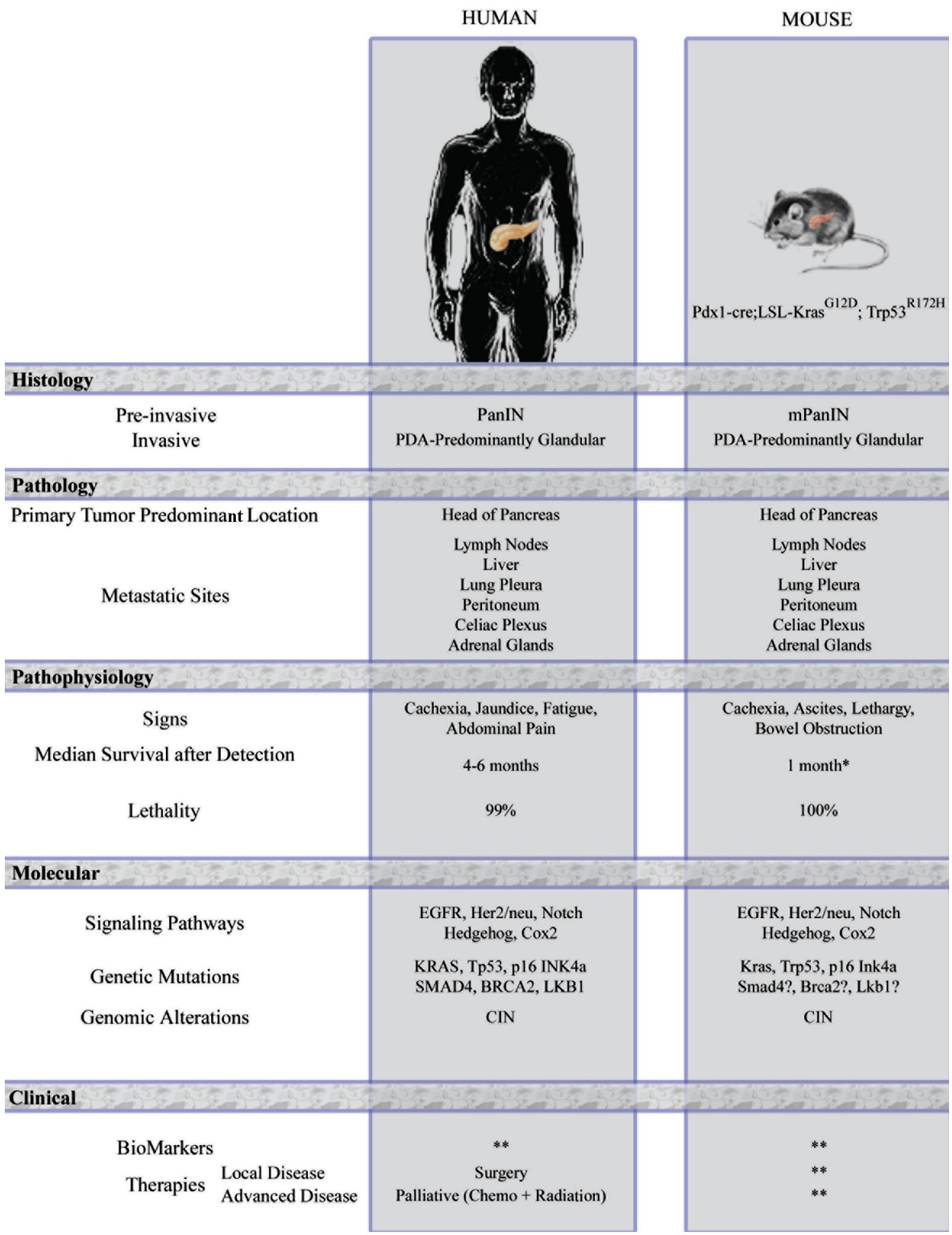

Figure 3. Comparison between human and murine PDA. Histological, pathological, pathophysiological, molecular, and clinical aspects of human and murine PDA. (*) Mouse PDA is detected by ultrasound; (**) under investigation.

supported the relevance of the PanIN model for the study of human PDA.

The murine PanIN and PDA models were further vali- dated by the elevated expression of several potential therapeutic targets previously identified in human PanIN and PDA, including EGFR, Her-2/neu, Sonic Hedgehog lig- 
and, Cox-2, matrix metalloproteinase 7, and an activated Notch signaling pathway. However, the expression of several of these targets was not uniform throughout tumors from the Pdx1-cre; Kras ${ }^{G 12 D}$; Trp $53^{R 172 H}$ mice, suggesting a profound underlying molecular heterogeneity. Primary cell lines prepared from these mice uniformly demonstrated the loss of the remaining wild-type Trp53 allele, but no mutations in the p16Ink4a, Cdk4 or Smad4/Dpc4/Madh4 gene. Notably, the isolated cell lines displayed impressive centrosome amplification, and karyotypic analysis revealed a widespread chromosomal instability that is uncommon in mouse tumor models but is a hallmark feature of human PDA and is thought to contribute to the molecular complexity of human epithelial cancers. Thus, these mouse models of PanIN and PDA faithfully recapitulated the central features of the cognate human condition at the clinical, histopathological, biochemical, genetic, and genomic levels (Fig. 3).

\section{CONCLUSION}

Murine models of PanIN and PDA have now been established and should serve as important components of the preclinical tool box for pancreatic cancer researchers (Hruban et al. 2006b). Much optimism exists that such models will serve an important role in the development of early detection methods and the assessment of potential therapeutic strategies. Furthermore, mouse models of PanIN and PDA should enable biological investigations into the cellular origins and molecular pathways required for pancreatic cancer development and maintenance, including topics as diverse as metastasis and chromosomal instability.

\section{ACKNOWLEDGMENTS}

The authors thank current and past Tuveson and Hingorani lab members and our outside collaborators who have contributed to this research. Particularly, we thank Dr. Ralph Hruban for photomicrographs of human PanIN and PDA, and Mike Jacobetz and Chelsea Combs for figure preparation. Funding is acknowledged from the AACR-PanCAN Career Development Award (S.R.H.), National Institutes of Health grants R01 CA101973 and U01 CA084291 (D.A.T.). D.A.T. is a Rita Allen Foundation Scholar.

\section{REFERENCES}

Aguirre A.J., Bardeesy N., Sinha M., Lopez L., Tuveson D.A., Horner J., Redston M.S., and DePinho R.A. 2003. Activated Kras and Ink4a/Arf deficiency cooperate to produce metastatic pancreatic ductal adenocarcinoma. Genes Dev. 17: 3112.

Ahlgren J.D. 1996. Epidemiology and risk factors in pancreatic cancer. Semin. Oncol. 23: 241.

Allison D.C., Piantadosi S., Hruban R.H., Dooley W.C., Fishman E.K., Yeo C.J., Lillemoe K.D., Pitt H.A., Lin P., and Cameron J.L. 1998. DNA content and other factors associated with ten-year survival after resection of pancreatic carcinoma. J. Surg. Oncol. 67: 151.

Bardeesy N., Sharpless N.E., DePinho R.A., and Merlino G. 2001. The genetics of pancreatic adenocarcinoma: A roadmap for a mouse model. Semin. Cancer Biol. 11: 201.
Berman D.M., Karhadkar S.S., Maitra A., Montes De Oca R., Gerstenblith M.R., Briggs K., Parker A.R., Shimada Y., Eshleman J.R., Watkins D.N., and Beachy P.A. 2003. Widespread requirement for Hedgehog ligand stimulation in growth of digestive tract tumours. Nature 425: 846.

Berthelemy P., Bouisson M., Escourrou J., Vaysse N., Rumeau J.L., and Pradayrol L. 1995. Identification of K-ras mutations in pancreatic juice in the early diagnosis of pancreatic cancer. Ann. Intern. Med. 123: 188.

Brembeck F.H., Schreiber F.S., Deramaudt T.B., Craig L., Rhoades B., Swain G., Grippo P., Stoffers D.A., Silberg D.G., and Rustgi A.K. 2003. The mutant K-ras oncogene causes pancreatic periductal lymphocytic infiltration and gastric mucous neck cell hyperplasia in transgenic mice. Cancer Res. 63: 2005.

Brummelkamp T.R., Bernards R., and Agami R. 2002. Stable suppression of tumorigenicity by virus-mediated RNA interference. Cancer Cell 2: 243.

Burris H.A., III, Moore M.J., Andersen J., Green M.R., Rothenberg M.L., Modiano M.R., Cripps M.C., Portenoy R.K., Storniolo A.M., Tarassoff P., Nelson R., Dorr F.A., Stephens C.D., and Von Hoff D.D. 1997. Improvements in survival and clinical benefit with gemcitabine as first-line therapy for patients with advanced pancreas cancer: A randomized trial. $J$. Clin. Oncol. 15: 2403.

Caldas C., Hahn S.A., Hruban R.H., Redston M.S., Yeo C.J., and Kern S.E. 1994. Detection of K-ras mutations in the stool of patients with pancreatic adenocarcinoma and pancreatic ductal hyperplasia. Cancer Res. 54: 3568.

Canto M.I., Goggins M., Yeo C.J., Griffin C., Axilbund J.E., Brune K., Ali S.Z., Jagannath S., Petersen G.M., Fishman E.K., Piantadosi S., Giardiello F.M., and Hruban R.H. 2004. Screening for pancreatic neoplasia in high-risk individuals: An EUS-based approach. Clin. Gastroenterol. Hepatol. 2: 606.

Chen R., Yi E.C., Donohoe S., Pan S., Eng J., Cooke K., Crispin D.A., Lane Z., Goodlett D.R., Bronner M.P., Aebersold R., and Brentnall T.A. 2005. Pancreatic cancer proteome: The proteins that underlie invasion, metastasis, and immunologic escape. Gastroenterology 129: 1187.

Crist D.W., Sitzmann J.V., and Cameron J.L. 1987. Improved hospital morbidity, mortality, and survival after the Whipple procedure. Ann. Surg. 206: 358.

DiGiuseppe J.A., Hruban R.H., Goodman S.N., Polak M., van den Berg F.M., Allison D.C., Cameron J.L., and Offerhaus G.J. 1994. Overexpression of $\mathrm{p} 53$ protein in adenocarcinoma of the pancreas. Am. J. Clin. Pathol. 101: 684.

Donehower L.A., Harvey M., Slagle B.L., McArthur M.J., Montgomery C.A., Jr., Butel J.S., and Bradley A. 1992. Mice deficient for p53 are developmentally normal but susceptible to spontaneous tumours. Nature 356: 215.

Eberle M.A., Pfutzer R., Pogue-Geile K.L., Bronner M.P., Crispin D., Kimmey M.B., Duerr R.H., Kruglyak L., Whitcomb D.C., and Brentnall T.A. 2002. A new susceptibility locus for autosomal dominant pancreatic cancer maps to chromosome 4q32-34. Am. J. Hum. Genet. 70: 1044.

Fukushima N., Sato N., Ueki T., Rosty C., Walter K.M., Wilentz R.E., Yeo C.J., Hruban R.H., and Goggins M. 2002. Aberrant methylation of preproenkephalin and p16 genes in pancreatic intraepithelial neoplasia and pancreatic ductal adenocarcinoma. Am. J. Pathol. 160: 1573.

Goggins M., Hruban R.H., and Kern S.E. 2000. BRCA2 is inactivated late in the development of pancreatic intraepithelial neoplasia: Evidence and implications. Am. J. Pathol. 156: 1767.

Goggins M., Schutte M., Lu J., Moskaluk C.A., Weinstein C.L., Petersen G.M., Yeo C.J., Jackson C.E., Lynch H.T., Hruban R.H., and Kern S.E. 1996. Germline BRCA2 gene mutations in patients with apparently sporadic pancreatic carcinomas. Cancer Res. 56: 5360.

Goldstein A.M., Fraser M.C., Struewing J.P., Hussussian C.J., Ranade K., Zametkin D.P., Fontaine L.S., Organic S.M., Dracopoli N.C., and Clark W.H., Jr. 1995. Increased risk of pancreatic cancer in melanoma-prone kindreds with p16INK4 mutations (comments). N. Engl. J. Med. 333: 970. 
Grippo P.J., Nowlin P.S., Demeure M.J., Longnecker D.S., and Sandgren E.P. 2003. Preinvasive pancreatic neoplasia of ductal phenotype induced by acinar cell targeting of mutant Kras in transgenic mice. Cancer Res. 63: 2016.

Gronborg M., Kristiansen T.Z., Iwahori A., Chang R., Reddy R., Sato N., Molina H., Jensen O.N., Hruban R.H., Goggins M.G., Maitra A., and Pandey A. 2006. Biomarker discovery from pancreatic cancer secretome using a differential proteomic approach. Mol. Cell. Proteomics 5: 157.

Guerra C., Mijimolle N., Dhawahir A., Dubus P., Barradas M., Serrano M., Campuzano V., and Barbacid M. 2003. Tumor induction by an endogenous K-ras oncogene is highly dependent on cellular context. Cancer Cell 4: 111.

Hansel D.E., Kern S.E., and Hruban R.H. 2003. Molecular pathogenesis of pancreatic cancer. Annu. Rev. Genomics Hum. Genet. 4: 237.

Hingorani S.R., Wang L., Multani A.S., Combs C., Deramaudt T.B., Hruban R.H., Rustgi A.K., Chang S., and Tuveson D.A. 2005. Trp53R172H and KrasG12D cooperate to promote chromosomal instability and widely metastatic pancreatic ductal adenocarcinoma in mice. Cancer Cell 7: 469.

Hingorani S.R., Petricoin E.F., Maitra A., Rajapakse V., King C., Jacobetz M.A., Ross S., Conrads T.P., Veenstra T.D., Hitt B.A., Kawaguchi Y., Johann D., Liotta L.A., Crawford H.C., Putt M.E., Jacks T., Wright C.V., Hruban R.H., Lowy A.M., and Tuveson D.A. 2003. Preinvasive and invasive ductal pancreatic cancer and its early detection in the mouse. Cancer Cell 4: 437.

Hruban R.H., Rustgi A.K., Brentnall T.A., Tempero M.A., Wright C.V., and Tuveson D.A. 2006a. Pancreatic cancer in mice and man: The Penn Workshop 2004. Cancer Res. 66: 14.

Hruban R.H., van Mansfeld A.D., Offerhaus G.J., van Weering D.H., Allison D.C., Goodman S.N., Kensler T.W., Bose K.K., Cameron J.L., and Bos J.L. 1993. K-ras oncogene activation in adenocarcinoma of the human pancreas. A study of 82 carcinomas using a combination of mutant-enriched polymerase chain reaction analysis and allele-specific oligonucleotide hybridization. Am. J. Pathol. 143: 545.

Hruban R.H., Adsay N.V., Albores-Saavedra J., Anver M.R., Biankin A.V., Boivin G.P., Furth E.E., Furukawa T., Klein A., Klimstra D.S., Kloppel G., Lauwers G.Y., Longnecker D.S., Luttges J., Maitra A., Offerhaus G.J., Perez-Gallego L., Redston M., and Tuveson D.A. 2006b. Pathology of genetically engineered mouse models of pancreatic exocrine cancer: Consensus report and recommendations. Cancer Res. 66: 95.

Jackson E.L., Willis N., Mercer K., Bronson R.T., Crowley D., Montoya R., Jacks T., and Tuveson D.A. 2001. Analysis of lung tumor initiation and progression using conditional expression of oncogenic K-ras. Genes Dev. 15: 3243.

Jaffee E.M., Hruban R.H., Canto M., and Kern S.E. 2002. Focus on pancreas cancer. Cancer Cell 2: 25 .

Jaffee E.M., Hruban R.H., Biedrzycki B., Laheru D., Schepers K., Sauter P.R., Goemann M., Coleman J., Grochow L., Donehower R.C., Lillemoe K.D., O'Reilly S., Abrams R.A., Pardoll D.M., Cameron J.L., and Yeo C.J. 2001. Novel allogeneic granulocyte-macrophage colony-stimulating factorsecreting tumor vaccine for pancreatic cancer: A phase I trial of safety and immune activation. J. Clin. Oncol. 19: 145.

Johnson L., Mercer K., Greenbaum D., Bronson R.T., Crowley D., Tuveson D.A., and Jacks T. 2001. Somatic activation of the K-ras oncogene causes early onset lung cancer in mice (comments). Nature 410: 1111

Kern S.E. 2000. Molecular genetic alterations in ductal pancreatic adenocarcinomas. Med. Clin. N. Am. 84: 691.

Klimstra D.S. and Longnecker D.S. 1994. K-ras mutations in pancreatic ductal proliferative lesions. Am. J. Pathol. 145: 1547.

Konner J. and O'Reilly E. 2002. Pancreatic cancer: Epidemiology, genetics, and approaches to screening. Oncology 16: 1615.

Laheru D. and Jaffee E.M. 2005. Immunotherapy for pancreatic cancer: Science driving clinical progress. Nat. Rev. Cancer 5: 459.

Lowenfels A.B., Maisonneuve P., DiMagno E.P., Elitsur Y.,
Gates L.K., Jr., Perrault J., and Whitcomb D.C. 1997. Hereditary pancreatitis and the risk of pancreatic cancer. International Hereditary Pancreatitis Study Group. J. Natl. Cancer Inst. 89: 442.

Luttges J., Schlehe B., Menke M.A., Vogel I., Henne-Bruns D., and Kloppel G. 1999. The K-ras mutation pattern in pancreatic ductal adenocarcinoma usually is identical to that in associated normal, hyperplastic, and metaplastic ductal epithelium. Cancer 85: 1703.

Lynch H.T., Voorhees G.J., Lanspa S.J., McGreevy P.S., and Lynch J.F. 1985. Pancreatic carcinoma and hereditary nonpolyposis colorectal cancer: A family study. Br. J. Cancer $\mathbf{5 2}$ : 271.

Lynch H.T., Smyrk T., Kern S.E., Hruban R.H., Lightdale C.J., Lemon S.J., Lynch J.F., Fusaro L.R., Fusaro R.M., and Ghadirian P. 1996. Familial pancreatic cancer: A review. Semin. Oncol. 23: 251.

Maire F., Micard S., Hammel P., Voitot H., Levy P., Cugnenc P.H., Ruszniewski P., and Puig P.L. 2002. Differential diagnosis between chronic pancreatitis and pancreatic cancer: Value of the detection of KRAS2 mutations in circulating DNA. Br. J. Cancer 87: 551.

Miyamoto Y., Maitra A., Ghosh B., Zechner U., Argani P., Iacobuzio-Donahue C.A., Sriuranpong V., Iso T., Meszoely I.M., Wolfe M.S., Hruban R.H., Ball D.W., Schmid R.M., and Leach S.D. 2003. Notch mediates TGF alpha-induced changes in epithelial differentiation during pancreatic tumorigenesis. Cancer Cell 3: 565.

Mora J., Puig P., Boadas J., Urgell E., Montserrat E., Lerma E., Gonzalez-Sastre F., Lluis F., Farre A., and Capella G. 1998. K-ras gene mutations in the diagnosis of fine-needle aspirates of pancreatic masses: Prospective study using two techniques with different detection limits. Clin. Chem. 44: 2243.

Moskaluk C.A., Hruban R.H., and Kern S.E. 1997. p16 and Kras gene mutations in the intraductal precursors of human pancreatic adenocarcinoma. Cancer Res. 57: 2140.

Picozzi V.J. and Traverso L.W. 2004. The Virginia Mason approach to localized pancreatic cancer. Surg. Oncol. Clin. N. Am. 13: 663.

Picozzi V.J., Kozarek R.A., and Traverso L.W. 2003. Interferon-based adjuvant chemoradiation therapy after pancreaticoduodenectomy for pancreatic adenocarcinoma. Am. J. Surg. 185: 476.

Quaife C.J., Pinkert C.A., Ornitz D.M., Palmiter R.D., and Brinster R.L. 1987. Pancreatic neoplasia induced by ras expression in acinar cells of transgenic mice. Cell 48: 1023.

Queneau P.E., Adessi G.L., Thibault P., Cleau D., Heyd B., Mantion G., and Carayon P. 2001. Early detection of pancreatic cancer in patients with chronic pancreatitis: Diagnostic utility of a K-ras point mutation in the pancreatic juice. Am. J. Gastroenterol. 96: 700.

Reya T., Morrison S.J., Clarke M.F., and Weissman I.L. 2001. Stem cells, cancer, and cancer stem cells. Nature 414: 105.

Rogers C.D., Van Der Heijden M.S., Brune K., Yeo C.J., Hruban R.H., Kern S.E., and Goggins M. 2004. The genetics of FANCC and FANCG in familial pancreatic cancer. Cancer Biol. Ther. 3: 167.

Rozenblum E., Schutte M., Goggins M., Hahn S.A., Panzer S., Zahurak M., Goodman S.N., Sohn T.A., Hruban R.H., Yeo C.J., and Kern S.E. 1997. Tumor-suppressive pathways in pancreatic carcinoma. Cancer Res. 57: 1731.

Serrano M., Lin A.W., McCurrach M.E., Beach D., and Lowe S.W. 1997. Oncogenic ras provokes premature cell senescence associated with accumulation of p53 and p16INK4a. Cell 88: 593.

Serrano M., Lee H., Chin L., Cordon-Cardo C., Beach D., and DePinho R.A. 1996. Role of the INK4a locus in tumor suppression and cell mortality. Cell 85: 27.

Silverman D.T., Dunn J.A., Hoover R.N., Schiffman M., Lillemoe K.D., Schoenberg J.B., Brown L.M., Greenberg R.S., Hayes R.B., and Swanson G.M., et al. 1994. Cigarette smoking and pancreas cancer: A case-control study based on direct interviews. J. Natl. Cancer Inst. 86: 1510. 
Sirard C., de la Pompa J.L., Elia A., Itie A., Mirtsos C., Cheung A., Hahn S., Wakeham A., Schwartz L., Kern S.E., Rossant J., and Mak T.W. 1998. The tumor suppressor gene Smad4/Dpc4 is required for gastrulation and later for anterior development of the mouse embryo. Genes Dev. 12: 107.

Su G.H., Hruban R.H., Bansal R.K., Bova G.S., Tang D.J., Shekher M.C., Westerman A.M., Entius M.M., Goggins M., Yeo C.J., and Kern S.E. 1999. Germline and somatic mutations of the STK11/LKB1 Peutz-Jeghers gene in pancreatic and biliary cancers. Am. J. Pathol. 154: 1835.

Suzuki A., de la Pompa J.L., Hakem R., Elia A., Yoshida R., Mo R., Nishina H., Chuang T., Wakeham A., Itie A., Koo W., Billia P., Ho A., Fukumoto M., Hui C.C., and Mak T.W. 1997. $\mathrm{Brca} 2$ is required for embryonic cellular proliferation in the mouse. Genes Dev. 11: 1242.

Tada M., Omata M., Kawai S., Saisho H., Ohto M., Saiki R.K., and Sninsky J.J. 1993. Detection of ras gene mutations in pancreatic juice and peripheral blood of patients with pancreatic adenocarcinoma. Cancer Res. 53: 2472.

Tada M., Ohashi M., Shiratori Y., Okudaira T., Komatsu Y., Kawabe T., Yoshida H., Machinami R., Kishi K., and Omata M. 1996. Analysis of K-ras gene mutation in hyperplastic duct cells of the pancreas without pancreatic disease (comments). Gastroenterology 110: 227.

Tang P.A., Tsao M.S., and Moore M.J. 2006. A review of erlotinib and its clinical use. Expert Opin. Pharmacother. 7: 177.

Terhune P.G., Phifer D.M., Tosteson T.D., and Longnecker D.S. 1998. K-ras mutation in focal proliferative lesions of human pancreas. Cancer Epidemiol. Biomark. Prev. 7: 515.

Thayer S.P., di Magliano M.P., Heiser P.W., Nielsen C.M., Roberts D.J., Lauwers G.Y., Qi Y.P., Gysin S., Fernandez-del Castillo C., Yajnik V., Antoniu B., McMahon M., Warshaw A.L., and Hebrok M. 2003. Hedgehog is an early and late mediator of pancreatic cancer tumorigenesis. Nature 425: 851.

Thorlacius S., Olafsdottir G., Tryggvadottir L., Neuhausen S., Jonasson J.G., Tavtigian S.V., Tulinius H., Ogmundsdottir H.M., and Eyfjord J.E. 1996. A single BRCA2 mutation in male and female breast cancer families from Iceland with varied cancer phenotypes (comments). Nat. Genet. 13: 117.

Trede M., Richter A., and Wendl K. 2001. Personal observations, opinions, and approaches to cancer of the pancreas and the periampullary area. Surg. Clin. N. Am. 81: 595.

Trede M., Schwall G., and Saeger H.D. 1990. Survival after pancreatoduodenectomy. 118 consecutive resections without an operative mortality. Ann. Surg. 211: 447.

Tuveson D.A., Zhu L., Gopinathan A., Willis N.A., Kachatrian L., Grochow R., Pin C.L., Mitin N.Y., Taparowsky E.J., Gimotty P.A., Hruban R.H., Jacks T., and Konieczny S.F. 2006. Mist1-KrasG12D knock-in mice develop mixed differentiation metastatic exocrine pancreatic carcinoma and hepatocellular carcinoma. Cancer Res. 66: 242.

Tuveson D.A., Shaw A.T., Willis N.A., Silver D.P., Jackson E.L., Chang S., Mercer K.L., Grochow R., Hock H., Crowley D., Hingorani S.R., Zaks T., King C., Jacobetz M.A., Wang L., Bronson R.T., Orkin S.H., DePinho R.A., and Jacks T.
2004. Endogenous oncogenic K-ras(G12D) stimulates proliferation and widespread neoplastic and developmental defects. Cancer Cell 5: 375.

Uehara H., Nakaizumi A., Tatsuta M., Baba M., Takenaka A., Uedo N., Sakai N., Yano H., Iishi H., Ohigashi H., Ishikawa O., Okada S., and Kakizoe T. 1999. Diagnosis of pancreatic cancer by detecting telomerase activity in pancreatic juice: Comparison with K-ras mutations. Am. J. Gastroenterol. 94: 2513.

van Heek N.T., Meeker A.K., Kern S.E., Yeo C.J., Lillemoe K.D., Cameron J.L., Offerhaus G.J., Hicks J.L., Wilentz R.E., Goggins M.G., De Marzo A.M., Hruban R.H., and Maitra A. 2002. Telomere shortening is nearly universal in pancreatic intraepithelial neoplasia. Am. J. Pathol. 161: 1541.

Van Laethem J.L., Vertongen P., Deviere J., Van Rampelbergh J., Rickaert F., Cremer M., and Robberecht P. 1995. Detection of c-Ki-ras gene codon 12 mutations from pancreatic duct brushings in the diagnosis of pancreatic tumours. Gut 36: 781 .

Villanueva A., Reyes G., Cuatrecasas M., Martinez A., Erill N., Lerma E., Farre A., Lluis F., and Capella G. 1996. Diagnostic utility of K-ras mutations in fine-needle aspirates of pancreatic masses. Gastroenterology 110: 1587.

Wagner M., Greten F.R., Weber C.K., Koschnick S., Mattfeldt T., Deppert W., Kern H., Adler G., and Schmid R.M. 2001. A murine tumor progression model for pancreatic cancer recapitulating the genetic alterations of the human disease. Genes Dev. 15: 286.

Warshaw A.L. and Fernandez-del Castillo C. 1992a. Pancreatic carcinoma. N. Engl. J. Med. 326: 455.

. 1992b. Pancreatic carcinoma. N. Engl. J. Med. 326: 455.

Wilentz R.E., Iacobuzio-Donahue C.A., Argani P., McCarthy D.M., Parsons J.L., Yeo C.J., Kern S.E., and Hruban R.H. 2000. Loss of expression of Dpc4 in pancreatic intraepithelial neoplasia: Evidence that DPC4 inactivation occurs late in neoplastic progression. Cancer Res. 60: 2002.

Wilentz R.E., Geradts J., Maynard R., Offerhaus G.J., Kang M., Goggins M., Yeo C.J., Kern S.E., and Hruban R.H. 1998. Inactivation of the p16 (INK4A) tumor-suppressor gene in pancreatic duct lesions: Loss of intranuclear expression. Cancer Res. 58: 4740.

Yanagisawa A., Ohtake K., Ohashi K., Hori M., Kitagawa T., Sugano H., and Kato Y. 1993. Frequent c-Ki-ras oncogene activation in mucous cell hyperplasias of pancreas suffering from chronic inflammation. Cancer Res. 53: 953.

Yang X., Li C., Herrera P.L., and Deng C.X. 2002. Generation of Smad4/Dpc4 conditional knockout mice. Genesis 32: 80.

Yokoyama M., Ochi K., Ichimura M., Mizushima T., Shinji T., Koide N., Tsurumi T., Hasuoka H., and Harada M. 2002. Matrix metalloproteinase-2 in pancreatic juice for diagnosis of pancreatic cancer. Pancreas 24: 344.

Yu K.H., Rustgi A.K., and Blair I.A. 2005. Characterization of proteins in human pancreatic cancer serum using differential gel electrophoresis and tandem mass spectrometry. J. Proteome Res. 4: 1742. 


\section{$8_{8}^{\infty} \mathrm{CSH} \&$ Cold Spring Harbor Symposia SYMPOSIA on Quantitative Biology}

\section{Ductal Pancreatic Cancer in Humans and Mice}

D.A. TUVESON and S.R. HINGORANI

Cold Spring Harb Symp Quant Biol 2005 70: 65-72

Access the most recent version at doi:10.1101/sqb.2005.70.040

References This article cites 81 articles, 24 of which can be accessed free at: http://symposium.cshlp.org/content/70/65.full.html\#ref-list-1

\section{License}

Email Alerting Receive free email alerts when new articles cite this article - sign up in Service the box at the top right corner of the article or click here. 